\title{
PERBANDINGAN EFEKTIFITAS ORAL HYGIENE MENGGUNAKAN ENZYM LACTOPEROXIDASE DENGAN CHLORHEXIDINE DALAM PENCEGAHAN VAP DI ICU RS X
}

\author{
Agus Purnama ${ }^{1}$, Raushan Fikri ${ }^{2}$ \\ ${ }^{1,2}$ Program Sarjana Keperawatan, Sekolah Tinggi Ilmu Kesehatan Indonesia Maju \\ Email : purnama.aguz@gmail.com
}

\begin{abstract}
ABSTRAK
Berbagai macam infeksi dapat terjadi pada pasien yang mengalami perawatan di rumah sakir seperti infeksi nosokomial atau yang kini lebih sering dikenal dengan Healthcare Assosiated Infections (HAI's). Infeksi nosokomial adalah infeksi yang didapat pasien dari rumah sakit pada saat pasien menjalani proses asuhan keperawatan. infeksi yang didapat dari rumah sakit yang terjadi pada pasien yang dirawat selama 72 jam dan pasien tersebut tidak menunjukkan tanda dan gejala infeksi pada saat masuk rumah sakit. VAP merupakan salah satu jenis infeksi nosokomial pada pasien yang terpasang ventilator umumnya setelah 48 jam sejak awal pemasangan ventilator mekanik. Dari data yang didapatkan dari unit Pencegahan dan Pengendalian Infeksi (PPI) didapatkan data pada bulan September 2018 Infeksi Daerah Operasi (IDO) 0,16\%, Hospital Aquired Pneumonia (HAP) 1,4\%, Ventilator Aquired Pneumonia (VAP) 2,8\%.VAP terjadi karena infeksi mikrooorganisme seperti Pseudomonas aeruginosa, Klebsiella pneumoniae, dan Enterobacter akibat dari pemasangan selang ETT yang menjadi jalan masuknya patogen ke dalam paru-paru. Sifat antibakteri obat kumur terutama ditentukan oleh bahan aktif yang terkandung didalamnya seperti Chlorhexidine dan Enzym Lactoperoxidase. Tujuan penelitian ini adalah membandingkan efektifitas oral hygiene menggunakan enzym lactoperoxidase dengan chlorhexidine dalam pencegahan vap di RS X. Jenis penelitian ini merupakan penelitian quasi eksperimen dengan rancangan penelitian Control Group Pretest-Posttest.Data yang digunakan dalam penelitian ini berupa data primer dengan teknik pengumpulan data menggunakan lembar observasi CPIS. Secara umum lembar CPIS berisi 6 parameter diagnosis VAP. Uji hipotesa menggunakan metode Independen T-Test. Hasil menunjukkan bahwa tidak ada perbedaan yang signifikan antara oral Hygiene dengan menggunakanEnzymLactoperoxide dan Chlorhexidine dalam pencegahan VAP di RS Xnilai $p=0,290$ (nilai $p>$ alpha 0,05)
\end{abstract}

Kata kunci : Ventilator Aquired Pneumonia, Oral hygiene, Lactoperoxide 


\title{
COMPARISON OF ORAL HYGIENE EFFECTIVENESS USING ENZYM LACTOPEROXIDASE WITH CHLORHEXIDINE IN VAP PREVENTION IN ICU RS X
}

\begin{abstract}
Various types of infections can occur in patients who experience care in a ward, such as nosocomial infections or what is now more commonly known as Healthcare Associated Infections (HAI's). Nosocomial infection is an infection that patients get from the hospital when the patient is undergoing a nursing care process. hospitalacquired infections occurred to patients that treated for 72 hours and these patients do not show signs and symptoms of infection at the time of admission to the hospital. Ventilator Aquired Pneumonia (VAP) is a type of nosocomial infection in patients who have a general ventilator after 48 hours from the start of the installation of a mechanical ventilator. Data obtained from the Infection Control and Prevention Control Unit (PPI) in September 2018 Surgery Area Infection (SAI) 0.16\%, Hospital Aquired Pneumonia (HAP) 1.4\%, Ventilator Aquired Pneumonia (VAP) 2.8\%. VAP occurs due to microorganism infections such as Pseudomonas aeruginosa, Klebsiella pneumoniae, and Enterobacter as a result of the installation of ETT tubes that become the pathogen entry into the lungs. The antibacterial mouthwash are mainly determined by the active ingredients contained in it such as Chlorhexidine and Enzym Lactoperoxidase. The purpose of this study was to compare the effectiveness of oral hygiene using the enzyme lactoperoxidase with chlorhexidine in the prevention of vap. Type of this research is a quasi-experimental study with a pretest-posttest control group research design. The data used in this study are primary data with data collection using CPIS observation sheets. In general, the CPIS sheet contains 6 diagnostic parameters for VAP. The hypothesis test uses the Independent T Test method. The results showed that there was no significant difference between oral hygiene using Lactoperoxide and Chlorhexidine in the prevention of VAP $p=0.290(p>$ alpha 0.05)
\end{abstract}

Keywords : VAP, Oral hygiene, Lactoperoxide, Chlorhexidine 


\section{PENDAHULUAN}

Salah satu infeksi yang dapat terjadi akibat paparan lingkungan yang menunjukkan tanda dan gejala infeksi adalah infeksi yang terjadi di rumah sakit atau lebih dikenal dengan istilah infeksi nosocomial. Infeksi ini terjadi pada pasien yang dirawat selama 72 jam pada saat masuk rumah sakit dan terpapar manifestasi klinis infeksi.Infeksi nosokomial sampai sekarang masih merupakan masalah perawatan kesehatan di rumah sakit seluruh dunia. Di Indonesia yaitu di 10 RSU pendidikan, infeksi nosokomial cukup tinggi yaitu 6-16\% dengan ratarata 9,8\% (Jeyamohan, 2010).

Pada pasien yang dipasangi ventilator, potensi terjadinya infeksi nosokomial dapat berupa Ventilator Assosiated Pneumonia (VAP). Angka kematian pasien yang mengalami VAP sebesar $30 \%$ dan dapat meningkat menjadi $70 \%$ seiring dengan penyerta lain seperti usia, riwayat kesehatan dan penyakitpenyakit kronis lainnya.Menanggapi hal tersebut pada tahun 2005 Institute for Healthcare Improvement (IHI) mengusulkan VAP bundle sebagai pencegahan VAP pada pasien-pasien di ICU. Beberapa peneliti mencoba untuk melakukan penelitin untuk mengurangi kejadian VAP Bundle diantaranya dengan pemberian profiliaksis Deep Vein Trombolitic (DVT), Pemberian profilaksis ulkus peptikum, dan pemberian penggunaan sedasi harian untuk penyapihan ventilator.dan bahkan ada penelitian yang menambahkan salah satu komponen yaitu perawatan mulut harian dengan menggunakan Chlorexididine.
Dari berbagai upaya pencegahan VAP yang dirangkum dalam VAP Bundle diatas, Oral Hygiene merupakan tindakan mandiri keperawatan, yang dampaknya sangat besar dalam keberhasilan pencegahan terjadinya VAP pada pasien yang terpasang ventilator.Chlorhexidine selain digunakan sebagai mouth wash, juga digunakan sebagai surgical scrub, neonatal bath \& general skin antiseptik..Chlorhexidine adalah salah satu jenis antiseptik dan disinfektan yang mempunyai efek bakterisidal dan bakteriostatik terhadap bakteri Gram (+) dan Gram (-).

Peroksidase (PO) merupakan salh satu katalisator enzim yang tersedia dalam jumlah yang banyak di dalam susu (kandungannya sekitar $30 \mathrm{mg} / \mathrm{l}$ susu). Penggunaan zat enzim seperti Lactoperoxidase memproduksi oksidan kuat dari mekanisme pertahanan nonimmune terhadap bakteri patogen, jamur, atau parasit yang membuat penggunaan enzim-enzim tersebut dalam aplikasi praktis.Reaksi enzimatik yang melibatkan peroksidase mamalia bersifat kompleks dan berbagai molekul dapatmenambah atau mengurangi secara dramatis aktivitas antibakteri.

Berdasarkan data awal yang didapatkan dari unit Pencegahan dan Pengendalian Infeksi (PPI) RS X didapatkan 3 kejadian infeksi 3 bulan terakhir di ruang ICU RS X sebagai berikut : bulan Juli 2018 Infeksi Daerah Operasi (IDO) 0,15\%, Hospital Aquired Pneumonia (HAP) 1,4\%, Ventilator Aquired Pneumonia (VAP) 7,55\%, bulan Agustus 2018 Infeksi Daerah Operasi (IDO) 0,6\%, Hospital Aquired 
Pneumonia

(HAP)

$0 \%$,

VentilatorAquired Pneumonia (VAP) 7,4\%, bulan Septemberi 2018 Infeksi Daerah Operasi (IDO) 0,16\%,Hospital AquiredPneumonia (HAP) 1,4\%, Ventilator Aquired Pneumonia (VAP) $2,8 \%$.

Berdasarkan latar belakang tersebut maka penelitian ini ditujukan untuk mengetahui bagaimana keefektifan oral Hygiene menggunakan chlorexidine dibandingkan dengan enzim Lactoperoxidase dalam pencegahan VAP di ruang ICU RS X Jakarta.

\section{METODE PENELITIAN}

Pada penelitian ini, peneliti menggunakan rancangan Control Group Pretest-Posttest.Jenis penelitian adalah quasi eksperimen. Sedangkan data yang digunakan berupa data primer dengan teknik pengumpulan data menggunakan lembar observasiCPIS. Secara umum lembar CPIS berisi 6 parameter diagnosis VAP. Uji hipotesa menggunakan metode Independan $\mathrm{T}$ Test.

Adapun tahapan yang dilakukan yaitu pertama-tama peneliti menetapkan kelompok yang akan dijadikan kelompok eksperimen yaitu Oral Hygiene dengan menggunakan Chlorhexidinedan Oral Hygiene.
Populasi pada penelitian ini adalah Pasien ICU RS $X$ yang terpasang Ventilator selama 3 bulan mulai dari 15 Nopember 2018 sampaidengan 15 Januari 2019. Adapun jumlahpasien ICU RS X yang terpasang Ventilator selama 3 bulan terakhir AgustusOktober 2018 adalah sebanyak 127 Pasien.Kiteria Inklusi ialah pasienpasien ICU yang baru masuk dan terintubasi di ICU sesuai indikasi medis selama <42 jam, usia produktif (20-55 th), dan keluarga yang bersedia berpartisipasi dalam penelitian. Kriteria eksklusi ialah pasien lansia $\left(>65^{\text {th }}\right)$, pasien dengan riwayat PPOK, pasien dengan riwayat re-intubasi, pasien dengan MDR TB, pasien dengan kontraindikasi dilakukan oral Hygiene, pasien sepsis, dan keluarga pasien yang tidak bersedia untuk berpartisipasi dalam penelitian.

\section{HASIL DAN PEMBAHASAN}

\section{Analisis univariat}

Analisis univariat dilakukan untuk mengetahui gambaran distribusi frekuensi variable yang diteliti yaitu jenis kelamin, usia, dan lama pemberian oral hygiene.

1. Kelompok Usia

Berikut ini akan diuraikan distribusi responden menurut kelompok usia menurut Depkes (2009).

Tabel 1. Distribusi Kelompok Usia Responden di ICU RS X Desember 2018 (N=40)

\begin{tabular}{ccc}
\hline Kelompok Usia & Jumlah & Persentase (\%) \\
\hline $26-35$ & 7 & $17,5 \%$ \\
$36-45$ & 12 & $30 \%$ \\
\hline
\end{tabular}




\begin{tabular}{ccc}
\hline $46-55$ & 13 & $32,5 \%$ \\
$56-65$ & 8 & 20 \\
\hline TOTAL & 40 & $100 \%$ \\
\hline
\end{tabular}

Tabel 1 menunjukkan bahwa jumlah responden menurut kategori usia paling banyak kategori usia 46-55 tahun $(32,5 \%)$. Sedangkan kelompok usia terendah yaitu usia 26-35 sebanyak $17,5 \%$
2. Jenis Kelamin

Berikut ini akan diuraikan distribusi responden menurut jenis kelamin.

Tabel 2. Distribusi Jenis Kelamin Responden di ICU RS X Desember 2018 (N=40)

\begin{tabular}{ccc}
\hline Jenis Kelamin & Jumlah & Persentase (\%) \\
\hline Laki-laki & 20 & $50 \%$ \\
Perempuan & 20 & $50 \%$ \\
\hline TOTAL & 40 & $100 \%$ \\
\hline
\end{tabular}

Berdasarkan table 2 di atas dapat diketahui bahwa jenis kelamin responden seimbang antara laki-laki dan perempuan yaitu masing-masing $50 \%$.

Kejadian di atas sesuai dengan penelitian yang di lakukan oleh GilMontoya, López I (2008) melakukan penelitian kualitatif pada Dua puluh orang tua dengan mulut kering dan dengan tingkat kemandirian tertentu untuk kegiatan kehidupan sehari-hari dimasukkan dalam studi percontohan ini. Sampel penelitian dilakukan pada 20 subjek terdiri dari 16 wanita dan 4 orang pria yang berusia rata-rata 81,3 tahun

Hasil penelitian ini menunjukkan bahwa kelompok usia yang lebih tua yaitu masa lansia awal (usia 46-55 tahun) menjadi kelompok mayoritas. Artinya bahwa lebih banyak pasien dengan usia yang lebih tua daripada usia muda. Hal ini disebabkan karena lansia mengalami proses penuaan pada semua organ yang menyebabkan lansia lebih rentan terkena suatu penyakit.

Menurut Tufail (2019) perubahan system imun lansia dimediasi dari infeksi kronis. Terdapat penurunan fungsi sel $\mathrm{B}$, penurunan regenerasi sel $\mathrm{T}$, gangguan aktivasi sel $\mathrm{T}$, gangguan fungsi neutrophil dan disregulasi respons inflamasi monosit. Perubahanperubahan tersebut menurunkan kemampuan tubuh untuk melawan infeksi.

3. Lama Hari Pelaksanaan Oral Hygiene 
Berikut ini akan diuraikan lama hari dilakukan kepada responden. pelaksanaan oral hygiene yang

Tabel 3. Lama Hari Pelaksanaan Oral Hygiene Responden di ICU RS X Desember 2018 $(\mathrm{N}=40)$

\begin{tabular}{ccc}
\hline Lama Hari & Jumlah Responden & Persentase $(\%)$ \\
\hline 2 hari & 3 & $7,5 \%$ \\
3 hari & 5 & $12,5 \%$ \\
4 hari & 5 & $12,5 \%$ \\
5 hari & 7 & $17,5 \%$ \\
6 hari & 3 & $7,5 \%$ \\
7 hari & 5 & $12,5 \%$ \\
8 hari & 12 & $30 \%$ \\
\hline TOTAL & 40 & $100 \%$ \\
\hline
\end{tabular}

Berdasarkan tabel 3, lama hari pelaksanaan oral hygiene bervariasi dari 2 hingga 8 hari. Hal tersebut tergantung dari lama hari rawat pasien di ICU dan lama hari pemakaian ventilator. Mayoritas responden yaitu 12 orang pasien dilakukan oral hygiene selama 8 hari. Hari terpendek pelaksanaan oral hygiene adalah 2 hari yaitu terjadi pada 3 orang responden.

Hasil di atas sesuai dengan penelitian yang dilakukan oleh (2013) meneliti pada pasien pasca operasi kardiovaskuler menggunakan pasta gigi dengan kandungan Chlorhexidine 0,12\% ditemukan Kejadian yang lebih rendah dari VAP $(2,7 \%$ [95\% CI 0,77,8 ] dibandingkan yang tidak menggunakan 8,7\% [95\% CI 4,9-14,7], $\mathrm{P}=0,04)$.

Dari penelitian di atas dapat disimpulkan bahwa lama hari pelaksanaan oral Hygiene akan berdampak langsung kepada efektifitas penggunaan lactoperoxide dan Chlorhexidine. Jika perawatan pasien yang lama menggunakan ventilator lebih cenderung akan mengalami VAP dikarenakan beberapa hal yaitu pasien yang bedrest total akan terjadi infeksi nosokomial yang akan memperburuk kondisi penyakit pasien.

\section{Kejadian VAP}

Berikut ini akan diuraikan perbandingan kejadian VAP pada responden dengan oral hygiene menggunakan Lactoperoxidase dan Chlorhexidine.

Tabel 4. Perbandingan Kejadian VAP Responden di ICU RS X Desember 2018 (N=40)

\begin{tabular}{ccc}
\hline Oral Hygiene & Jumlah & Persentase (\%) \\
\hline Lactoperoxidase & 5 & $62,5 \%$ \\
Chlorhexidine & 3 & $37,5 \%$ \\
\hline TOTAL & 8 & $100 \%$ \\
\hline
\end{tabular}


Berdasarkan tabel 4, dapat dilihat bahwa terjadi VAP pada 8 pasien dari total 40 responden. Responden yang dilakukan oral hygiene dengan Lactoperoxidase lebih banyak mengalami VAP yaitu 5 orang dibandingkan oral hygiene dengan chlorhexidine (3 orang).

\section{Analisis bivariat}

Analisis bivariat dilakukan untuk menentukan adanya perbedaan efektifitas oral hygiene dengan menggunakan Lactoperoxidase dibandingkan dengan Chlorhexidine untuk mencegah VAP di ICU RS X.Berdasarkan hasil uji kenormalan data di atas didapatkan hasil bahwa distribusi data penelitian ini merupakan distribusi normal sehingga ujihipotesis akan dilakukan dengan pendekatan uji statistic parametric (Hastono, 2007). Pengujian data penelitian ini menggunakan uji T 2 variabel independen.parametric (Hastono, 2007). Pengujian data penelitian ini menggunakan uji $\mathrm{T} \quad 2$ variabel independen.

Tabel 5. Distribusi Total Skor CPIS Responden Menurut Penggunaan Bahan Oral Hygiene Di ICU RS X Bulan Desember 2018

\begin{tabular}{ccccccc}
\hline Oral Hygiene & Mean & SD & SE & $\begin{array}{c}\mathrm{p} \\
\text { Levene } \\
\text { test }\end{array}$ & $\begin{array}{c}\mathrm{p} \\
\text { value }\end{array}$ & $\mathrm{N}$ \\
\cline { 1 - 4 } Lactoperoxidase & 4.75 & 0.851 & 0.190 & 0.290 & 0.843 & 20 \\
\hline Chlorhexidine & 4.70 & 0.733 & 0.164 & & & 20 \\
\hline
\end{tabular}

Pada tabel di atas dapat dilihat nilai rata-rata skor CPIS, standar deviasi dan standar eror untuk masing-masing kelompok. Rata-rata skor CPIS pada kelompok yang dilakukan oral hygiene dengan lactoperoxide adalah 4,75 dengan standar deviasi 0,851 . Sedangkan pada kelompok yang dilakukan oral hygiene dengan chlorhexidine adalah 4,70 dengan standar deviasi 0,733 .

Hasil uji $\mathrm{T}$ menunjukkan nilai $\mathrm{p}$ Levene test menghasilkan nilai $\mathrm{p}=$ 0,290 (nilai $\mathrm{p}>$ alpha 0,05) maka dapat disimpulkan bahwa tidak ada perbedaan varian (varian kedua kelompok sama). Selanjutnya, $\mathrm{p}$ value uji $\mathrm{T}$ pada equal variances yaitu sebesar 0,843 artinya bahwa pada alpha 5\% terlihat tidak ada perbedaan yang signifikan nilai total CPIS antara kelompok oral hygiene dengan Lactoperoxide dengan Chlorhexidine.

Hal ini sejalan dengan yang dikemukakan oleh WHO mengenai bundles untuk pencegahan VAP yaitu menggunakan Chlorhexidine untuk oral Hygiene. Selain itu, penelitian yang dilakukan oleh Chan, Ruest, Meade \& Cook (2007) menunjukkan bahwa penggunaan antiseptic oral secara signifikan dapat menurunkan kejadian VAP (0.56, 0.39 ke 0.81). Chlorhexidine cocok untuk digunakan sebagai antiseptic oral Hygiene karena dapat bekerja secara cepat pada 
berbagai target lokasi dan lebih rentan terjadi resistensi (Chan, Ruest, Meade \& Cook, 2007).

Penelitian

tentang

Lactoperoxidasedilakukan oleh Kirstilä V1, Lenander-Lumikari M, Söderling E, Tenovuo J (1996) meneliti tentang pengaruh oral Hygiene dengan produk pembersih mulut yang mengandung Lactoperoxidase, lysozyme dan lactoferrin pada komposisi saliva utuh dan gejala oral subjektif pada pasien dengan xerostomia. Penelitian ini mengevaluasi efek dari dua produk kebersihan mulut yang mengandung agen antimikroba nonimmunoglobulin pada seluruh air liur dan pada gejala oral subjektif pada pasien dengan xerostomia. 20 pasien menggunakan pasta gigi yang mengandung sistem laktoperoksidase

(Biotene)

dikombinasikan dengan penggunaan obat kumur (Biotene), yang juga mengandung lisozim dan laktoferin, selama 4 minggu.

Sampel air liur dikumpulkan pada garis dasar, setelah empat minggu penggunaan produk, dan pada akhir periode pencucian empat minggu. Sampel dianalisis untuk faktor biokimia dan mikrobiologi yang dipilih. Efek pada gejala oral subjektif juga dicatat. Penggunaan pasta gigi dan obat kumur setiap empat minggu mengurangi gejala kekeringan mulut pada 16 pasien.

Tingkat aktivitas salivariosianit, lysozyme, laktoferin, atau myeloperoxidase saliva tidak berubah, tetapi ada penurunan $\mathrm{pH}$ saliva yang signifikan $\quad(\mathrm{P} \quad<0,05)$, aktivitas peroksidase total $(\mathrm{P}<0,05)$, dan kandungan protein total $(\mathrm{P}=0,01)$.
Pada pasien dengan tingkat aliran saliva terendah $(\mathrm{n}=5)$ peningkatan yang signifikan $(\mathrm{P}>$ atau $=0,04)$ terdeteksi pada konsentrasi salivariosianit saliva. Tidak ada perubahan besar yang terjadi pada mikroflora saliva.

Angka kejadian VAP dapat diturunkan dengan bundle vap, salah satu komponen bundle VAP adalah penggunaan Chlorhexidine untuk oral Hygiene, dimana fungsi dari Chlorhexidine yaitu membunuh sel bakteri gram (+) dan bakteri gram (-). Sedangkan Lactoperoxidase berfungsi membunuh bakteri dengan memanfaatkan antimikroba alami yang ada dalam kandungan saliva.

Kejadian VAP pada pasien yang menggunakan lactoperokside adalah pasien yang mengalami perawatan yang lama. Sementara pasien yang menggunakan ventilasi mekanik mengalami penurunan sestem imunitas sehingga efektefitas Lactoperoxidase menjadi bias. Dari uraian di atas dapat disimpulkan bahwa dalam pencegahan VAP di RS XChlorhexidine lebih efektif dari Lactoperoxidase.

\section{SIMPULAN}

Berdasarkan hasil penelitian dan pembahasan yang telah diuraikan, maka penulis dapat menyimpulkan bahwa :Berdasarkan karakteristik usia responden yang mengalami kejadian VAP paling banyak pada usia lansia awal (45-55) tahun .Berdasarkan karakteristik jenis kelamin, responden yang mengalami kejadian VAP seimbang antara laki-laki (50\%) dan perempuan $(50 \%)$.Oral hygiene tidak ada perbedaan yang signifikan antara 
oral Hygiene dengan menggunakan Enzym Lactoperoxide dan Chlorhexidine dalam pencegahan VAP.

\section{UCAPAN TERIMA KASIH}

Pada kesempatan ini, peneliti ingin mengucapkan terima kasih kepada berbagai pihak yang telah membantu terwujudnya penelitian ini :

1. Ketua Sekolah Tinggi Ilmu Kesehatan Indonesia Maju

2. Ketua Lembaga Penelitian dan Pengabdian Sekolah Tinggi Ilmu Kesehatan Indonesia Maju

3. RS tempat penelitian ini dilakukan,

\section{DAFTAR PUSTAKA}

Ali, S. N. (2013). Critical Care Nurses'

Knowledge and compliance with

Ventilator Associated Pneumonia bundle at Cairo University Hospitals. Journal of Education and $\operatorname{Pr}, 4(15)$, 66-78.

Abdulkareem. (2014). Nurse Practice

Concering Mouthcare For

Unconscious Or Debilitated

Patient, INJCTR, 104-108.

American Thoracic Society. (2005). Mechanical ventilation. American Journal Respiratory Critical Care. Vol 172 P1

Amoian, B., Omidbakhsh, M., Khafri, S. (2017).The Clinical Evaluation Of Vi-One ChlorhexidineMouthwash On Plaque-Induced Gingivitis: aDoubleBlindRandomized Clinical Trial, Electronic Physician (ISSN: 2008-5842),5223-5228.
Aziz Alimul, Hidayat. 2007. Metode Penelitian dan Teknik Analisis Data. Jakarta:Salemba Medika Brooker, C. (2008). Ensiklopedia keperawatan, (edisi Bahasa Indonesia), alih bahasa Andry hartono et al. Jakarta: EGC

Centers for Disease Control \& Prevention. (2018). Pneumonia Ventilator-associated VAP and nonventilatorassociated Pneumonia (PNEU) Event. Device Assosiated Module. 1-15.

Chastre, J.,\& Fagon J. Y.(2002). Ventilator-associated Pneumonia. Am J Respir Crit Care Med Vol 165. $867-$ 903.http://0.1164/rccm.2105078.

Chan, E. Y., Ruest, A., Meade, M. O., \& Cook, D. J. (2007). Oral decontamination for prevention of pneumonia in mechanically ventilated adults: systematic review and meta-analysis. Bmj, 334(7599), 889.

Dahlan, M. Sopiyudin. 2009. Besar Sampel dan Cara Pengambilan Sampel dalam Penelitian Kedokteran dan Kesehatan. Jakarta : Salemba Medika

Darmadi. 2008.Infeksi Nosokomial :Problematika Dan Pengendaliannya.Jakarta: Penerbit Salemba Medika.

Deden, K. (2015). Ventilation modes in intensive care, $0-72$. Retrieved from http://www.draeger.com/sites/assets/ PublishingImages/Products/savina300/UK/9066477-BookletNomenklatur-engl-161111.pdf

F. Bafort,O. Parisi,J.-P. Perraudin, \& M. H. Jijakli. (2014). Mode of Action 
of Lactoperoxidase as Related to Its Antimicrobial Activity: A Review. Hindawi Publishing Corporation. http://dx.doi.org/10.1155/2014/517 164

Gil-Montoya, J. A., Guardia-López, I., \& González-Moles, M. A. (2008). Evaluation of the clinical efficacy of a mouthwash and oral gel containing the antimicrobial proteins lactoperoxidase, lysozyme and lactoferrin in elderly patients with dry mouth-a pilot study. Gerodontology, 25(1), 3-9.

Gomes, P. V. R. (2010). Knowledge of intensive care nurses on evidence based guidelines for prevention of ventilator associated pneumonia, 1166

Handoko, T. Hani, 2008. Manajemen Personalia Sumber Daya Manusia, Edisi Kedua,Yogyakarta, Penerbit : BPFE.

Hastono, S. P. (2007). Analisis data kesehatan. Depok: Fakultas Kesehatan Masyarakat Universitas Indonesia, 217.

Hooser DT. (2002). Ventilator associated pneumonia (VAP). Best practice for caregiver 2002: $1-17$

Jayatmi, I., \& Imaniyah, E. (2019).

Determinan Kejadian Infeksi

Saluran Pernapasan Akut (ISPA)

pada Balita. Jurnal Ilmiah

Kebidanan Indonesia, 9(01), 18-25.

Jeyamohan, D. (2010). Angka

prevalensi infeksi nosokomial pada pasien luka operasi pasca bedah di Bagian Bedah di Rumah Sakit Umum Pusat Haji Adam Malik, Medan dari bulan April sampai September 2010.
Jones S. B. , West N. , Nesmiyanov P. P. , Krylov S. E. , Klechkovskaya V. V., Arkharova, N. A. \& Zakirova S. A. (2018). The antibacterial efficacy of a foam mouthwash and its ability to remove biofilms. BDJ Open (2018) 4:17038; https://doi.org/10.1038/s41405018-0005-5

Kalanuria, A. A., Zai, W., \& Mirski, M. (2014). Ventilator-associated pneumonia in the ICU. Critical Care (London, England), 18(2), 18. http://doi.org/10.1186/cc13775

Lambert, M.-L., Palomar, M., Agodi, A., Hiesmayr, M., Lepape, A., Ingenbleek, A., Frank, U. (2013). Prevention of ventilator-associated pneumonia in intensive care units: an international online survey. Antimicrob Resist Infect Control, 2(1), 1. http://doi.org/10.1186/20472994-2-9

Lawrence P., Fulbrook P., (2010). The ventilator care bundle and its impact on ventilator-associated pneumonia: a review of the evidence. BACCN Nursing In Critical Care. Vol 16 No. 5. 222-232

Lynch, S. (2013). Mechanical Ventilation for the Adult. AMN Healthcare Educatio Services

Meller W., Schubert, Schwahn, A Kramer and Below H. (2009). Effect Of Lactoperoxidase On The Antimicrobial Effectiveness Of The Thiocyanate Hydrogen Peroxide Combination In a Quantitative Suspension Test. BMC Microbiology 
Munro, N., \& Ruggiero, M. (2014). Ventilator-Associated Pneumonia Bundle. AACN Advanced Critical Care, 25(2), 163-175. http://doi.org/10.1097/NCI.0000000 000000019.

Notoatmodjo, Soekidjo. 2012. Promosi kesehatan dan Perilaku Kesehatan. Jakarta : Rineka cipta.

O'Keefe-McCarthy, S., Santiago, C., \& Lau, G. (2008). Ventilator-associated pneumonia bundled strategies: an Evidence-based practice.Worldviews on Evidence-Based Nursing, 5(4): 193 204 (33 ref).

Potter, P.A, Perry, A.G.Buku Ajar Fundamental Keperawatan : Konsep, Proses, dan Praktik.Edisi 4.Volume 2.Alih Bahasa : Renata Komalasari,dkk.Jakarta:EGC.20 05

Price, A. Sylvia, Lorraine Mc. Carty Wilson, 2006, Patofisiologi : Konsep Klinis Proses-proses Penyakit, Edisi 6, (terjemahan), Peter Anugrah, EGC, Jakarta

Reyes, Ruppert, Yun S., Shiao P. (2007). Evidence-Based Practice: Use Of The Ventilator Bundle To Prevent Ventilator-Associated Pneumonia American Journal Of Critical Care, January 2007, Volume 16, No. 1, 20-27.

Sastroasmoro, S. 2011. Dasar-Dasar Metodologi Penelitian Klinis. Jakarta : Sagung Seto.
Selma Basyigit. (2018). Clinical Pulmonary Infection Score (CPIS) as a Screening Tool in Ventilatory Associated Pneumonia (VAP). The Medical Bulletin of Sisli Etfal Hospital, Volume: 51, Number 2, 2017. 133-141.

Singh, Surender. 20017. Pharmacology for Dentistry. New Delhi : New Age International (P) Limited, Publishers

Stanley, M. Patricia Gauntlett Beare. 2007. Buku Ajar Keperawatan Gerontik Edisi $2 . \quad$ Jakarta: EGC

Sugiyono, 2009, Metode Penelitian Kuantitatif, Kualitatif dan R\&D, Bandung : Alfabeta.

Torpy Janet M., (2012). Peptic Ulcer Disease. The Journal of the American Medical Association. Vol 307, No 12, Page 1329.

Tufail, M., Moon, Y., \& Kim, K. (2019). Rehabilitation Design Intervention for Older Adult Women through Community-based Co-Design Activities.

Venkatram, S., Nayak, J., \& Kanna, B. (2010). Safety of daily sedation interruptions in mechanically ventilated inner city patients -an alternative approach. Journal of Medicine and Medical Science, 1(July), 242-247. 